УАК 351.753.3(497.11)"1918/1941"

799.31(497.11)"1918/1941"

355.54(497.11)"1918/1941"

doi: $10.5937 /$ bastina31-31680

Pregledni rad

Dalibor Z. VELOJIĆ*

Institute for Serbian Culture Priština - Leposavić

\title{
THE INFLUENCE OF THE ARMY ON DEVELOPMENT OF SHOOTING SPORT IN NIŠ 1918-1941
}

\begin{abstract}
This paper, based on archives and adequate literature, deals with development of shooting sport in Niš during the two world wars. Members of the Army had a significant role in developing this sport as founders, club presidents and the main support.
\end{abstract} kingdom.

Key words: Shooting, army, Niš, sport, garisson, The Falcon of the Yugoslav

The influence of the army on developing sports in Niš in the period between two world wars, should be considered as part of the general problem of the socalled militarization of physical culture, adopted by the Kingdom of Yugoslavia following the practice in other European countries (Bjelajac 1994: 255). Promotion of sports and soldier skills, for the purpose of military fitness, held a special place in plansof European countries, considering the nature of World War I which called for mobilization of numerous human and economic resources (Velojić 2014: 221). Compulsory military service provided greater knowledge about the armed forces, but prior to recruitment most young people were not acquainted enough with the problems of defending the country. (Panić 1927: 87-95).

After the war, such involvement of young people forced itself upon many European countries, particularly the defeated ones (Germany, Bulgaria, Hungary), after limiting their military efficiency and putting it down to the minimum necessary for keeping the order. Organizing young people into various sport-military or semi-military formations, as well as physical training with military elements enabled the defeated countries to enhance their armies without fear of any control (Žutić 1991: 63-64). The higher number of military trained young men led to greater and greater activity of other countries, protectors

* Research associate, d.velojic@yahoo.com 
of the Treaty of Versailles, as potentially endangered, to carry out their systems of upbringing young people. Countries such as the France, Great Britain, USA, Czechoslovakia, Poland and USSR went the furthest within the framework of their institutions and ministries of physical culture (Žutić 1991: 64-65).

The Kingdom of Yugoslavia followed the trends, particularly since it was surrounded by revisionist states such as Italy, Hungary and Bulgaria. Fear of the neighbouring countries was proved in mid-thirties when it became clear that the system created at Versailles conference was not sustainable. Therefore, physical upbringing of the young called for a special strategy of the country as well as financial and expert assistance to organizations conducting such upbringing. Such a strategy was necessary, considering the worrying health condition of recruits in the first years after the war, $30 \%$ out of whom were deemed unfit for service (Bjelajac 1994, 255-257).

"Military activities in this field, primarily reflect themselves in cooperation with the organization the Falcon of the Yugoslav Kingdom, which trained fit young men through sport and military skills, good at using weapons and used to discipline and physical strain. In addition to this organization, various sport societies, such as shooting, riding, aero and yachting clubs, contributed to conducting pre-military training. Military authorities in every garrison kept close contact with these organizations, while the officers (very often founders of such associations) had the task to take an active part in their activity." (Velojić 2014: 222).

"Cooperation with sport societies of the Niš garrison, was significant above all, for raising the level of physical culture of the young and preparing them for the strains ofmilitary service. As a strategic military centre in the Kingdom of Yugoslavia (controlling part of the border with Bulgaria from the mouth of the Timok river in the north as far as Kriva Palan$k a$ in the south), Niš was the seat of a strong garrison comprising different military branches. We have to mention the headquarters of 5th army and Morava division area, as well as the headquarters of 2 nd cavalry division, together with regiments of the main branches (16th infantry, 1st cavalry, 1st pioneer, one artillery regiment and three independent artillery divisions, as well as the Velosiped battalion). At the end of the thirties, the headquarters of 5th fighter aviation regiment was established at Niš airport, and following the forming of the Assault Command, a special battalion characterised by complex military training and strict people selection was added to the garrison. The presence of such units in the city must have contributed to stronger cooperation on promoting sport and militarization of physical culture." (Velojić 2014: 223).

The influence of the army on developing physical culture among young people was primarily carried out through falcon associations. The Falcon of the Yugoslav kingdom association was founded in 1929, upon introduction of dictatorship. ${ }^{1}$ This organisation hadits own ideological programme, by means

1 Similarly to military, the falcon society had its own formation and organisation. There existed falcon troops, which carried out training and practice, and often brotherhoods were formed in places where circumstances did not allow for establishment of stronger falcon organisation (IAN, Varia 181, p.1, The rules of the Falcon society). 
of which it stopped being a movement and became a state institution (Dimić I 1996, 434-435). The basic purpose and goal of this society was to promote the idea of integral Yugoslavism, through its activities among young people in the area of sport and development of physical culture. The connection of falconry with the army would be, according to general Knežević:

„In common moral and physical upbringing, but while the falconry educated its members from the age of six, both sexes included, the army trained its members during military service. In order to accomplish their tasks successfully, the falconry needed to have organization similar to that of the military, which reflected in formation of units and introduction of military command. Thus, falconry prepared young men for military skills and habits, taught them obedience and polite behaviour, producing physically healthy young men, resistant and tough, fit for the greatest strains of the body and mind" (Knežević 1931, 109-111).

The relationship of the army and the falcon association was based on mutual assistance, since the goal was to bring falconry closer to army members, but also organize military organisation into falcon troops (Žutić 1991, 66).

The falcon movement presented an ideal way to promote military upbringing in young people. In addition to physical exercise, this organization combined exercise with elements of military training such as shooting, equestrian sports and close-order drill. Training courses for soldiers to become leaders of falcon troops were organized, which enabled this activity to continue in civil life after completion of military service (Brozović 1930: 88; Žutić 1991: 66-67). The Law on military defense regulated the cooperation between the Ministry of the Army and Navy and the Ministry of Sport. ${ }^{2}$ Besides, the recruits who were members of the falcon associations were given certain benefits. After spending five years in the falcon society, they were entitled to a reduction in military service of three months ( 45 days in case of reduced service), as well as to priority of promotion into rank of corporal and sergeant. ${ }^{3}$

Shooting, as purely military discipline, was welcomed by the young in Niš. After liberation from the Turks, a group of teachers, reserve officers, founded the first shooting society in Niš (1881). In later years, several such societies were formed in the neighbouring places, and consequently the competitions started. Until the start of the Balkan wars, the city of Niš with the vicinity boasted a number of about 60,000 members divided into 112 shooting societies (Istorija Niša II 1984, 536; Enciklopedija Niša, sport 2015: 450).

World War I interrupted development of this sport for a short time, but in 1924 shooting organisations were re-established in the kingdom. The influence of the army on these activities is best shown by the official proclamation of the Ministry of the Army and the Navy from 1926, which stated that officers

2 SVL, 1930, article 28.

3 SVL, 1930, article 1. 
were to be initiators and pillars of the shooting sport. Two years later, the decree on decoration was passed, which enabled good shooters to be awarded medals, while the Shooting Federation was assigned its own flag. In shooting competitions, presence of representatives of the King, Ministry of the Army and the Navy as well as respected military officers and citizens was compulsory. Since the state had a significant role in popularization of this sport, the number of shooting societies in the Kingdom of Yugoslavia rose to 1,600 with the total of around 80,000 members during the thirties. It is considered that shooting, together with football, had the greatest number of supporters on the territory of the whole kingdom (Žutić 1991: pg.74-75). Shooting societies had the best cooperation with the falcons, where handling fire weapons was part of regular training. For this purpose, shooting departments were formed within the falcon societies, with the primary aim to prepare future soldiers, but also competitors in shooting competitions.

Between the two world wars, the shooting sport in Niš and its vicinity was organized in societies that had internal independence. The societies were named after the places they had been formed in, and they were subjectto The Shooting Society Federation, with the seat in Belgrade. According to the draft of the Law on shooting societies from 1934, the supervisory body of the shooting federation was the Ministry of Sport, which carried out decisions and supervised the completion of tasks. Besides, control of handling and maintenance of the weapons, proper use and ammunition expenditure, was performed by the Ministry of the Army and the Navy, which indicates that due to sensitive character of shooting sport, control had to be strengthened and delimited to two ministries. ${ }^{4}$

Territorial devision of the Shooting Federation included shooting districts which united the activity of shooting societies. What is important is that the shooting territory matched the corresponding territory of the military district. We could freely say that the military district of Niš was authorized for all shooting societies in the territory of the city and its vicinity. The members of the societies

4 In addition to this, a recommendation for the draft law on the organization of the Army and the Navy was made, which would approve the same benefits regarding shorter military service as in the case of falcons, and under the same conditions (AJ, 71, f1,1). In the letter from 27 December 1937, the military minister opposed the draft law on shooting societies, stating the reasons according to which shooting should be exclusively under authority of the Ministry of the Army and the Navy. In his opinion, shooting was naturally closer to military shooting skill than a sport, and should be considered a semi-military organization. Dual control would be bad for supervision, since it would bring about the clash of authority, as it was difficult to delimit them. Finally, he cited the harmful effect of political circumstances on shooting organizations, which would not exist in the case of absolute military control. The Minister of Sport replied that mutual work of the two ministries had to exist, since it was a specific sport with military elements, funded not from the military but civilian part of the budget, therefore the Ministry of sport was to determine the plan and program of training and competitions (AJ, 71, f1,1). 
had to be from the territory of Niš and older than $18 .{ }^{5}$ The shooting district of Niš had its district assembly and its own administration. The district assembly was comprised of delegates from all shooting societies in the district, while their number was determined according to the number of members. Societies of up to 100 regular members gave one delegate, from 100 to 300 members two delegates, and over 300 members three delegates. ${ }^{6}$ The assembly session was scheduled regularly, once a year, or more often if necessary. The administration of the district comprised of the administrative and supervisory boards elected by the assembly in regular meetings. The administrative board consisted of 9 members and 3 deputies, while the supervisory one had 3 members and 2 deputies, elected annually, and constituted immediately after the election. According to the rule book, two thirds of the members had to have residential address on the territory of Niš city. ${ }^{7}$ Formation of new and renewal of old shooting societies in the territory of Niš district, was accompanied by lack of resources, financial as well as material. For this purpose, the newly founded societies received from the military authorities two rifles and 2,000 bullets each,f ree of charge, as support at the beginning, and later three to ten rifles and 1,000 bullets with $75 \%$ discount, respectively. ${ }^{8}$ Equally important was to provide the range for shooting practice. This was a major problem, due to specific nature of the shooting sport. Namely, according to instructions issued by the Ministry of the Army, the garrisons were under obligation to yield the shooting field to the city club (when army units were not practising shooting) for practice and competitions. The city of Niš had a well-organized shooting rangefor civilian needs near the area Apelovac. This field, military in character, near the brewery, was used for civilian competitions as early as the beginning of the 20th century. 200 metres long and 20 metres wide, the field was appropriate for training and competitions. It possessed an earth trench and ramparts, and to provide shelter in case of rain, the canopy was built (Enciklopedija Niša, sport 2015: 414). ${ }^{9}$

The civilian shooting field could surely be used for military purpose, if needed, as depicted in an episode of exchanging land between the city and the garrison.

5 According to draft law on shooting societies, the younger members formed a club of the shooting youth and couldpractise only with school weapons (AJ, 71, f38, 123, p. 4, Rules of federal shooting society). The proposition by the Ministry of the Army and the Navy from 1936, that secondary school students could be members of shooting societies was rejected by the Minister of Education, with the explanation that secondary school students could be members exclusively of the Red Cross, Falcons and Ferial Association (AJ, 71, f 1, 1).

6 AJ, 71, f.1,1, Draft of the Law on shooting societies.

7 AJ, 71, f.1,1.

8 SVL, 1933, 685.

9 The shooting area was also used by neighbouring military districts. Thus, at the end of June 1934, the competition of shooters from Prokuplje military district was held (Niške novine, July 8, 1934: 4). 
According to the report of the head of the engineer-technical department given to the military minister from 1933, the municipal court in Niša sked to be given a part of military-state land, area of $13,480 \mathrm{~m} 2$ at the corner of Vojvoda Putnik and Stevan Sremac streets in King Petar square, which was a constituent part of infantry military barracks area „Knjaz Mihailo“. This spot was planned for the new elementary school building for residential area Bubanj, as well as for the square. In replacement for this spot, Niš municipality offered its own land, area of 33,800 $\mathrm{m} 2$ near Apelovac, on civilian shooting area. ${ }^{10}$ Following this exchange there were contradictory opinions between Niš municipality and military authorities, since state land was worth more than municipal, so additional payment was demanded. The dispute was solved when the Ministers of military affairs and finances intervened, with the explanation that land given to the municipality was useless for military purposes, while the one near Apelovac might serve as the shooting range. ${ }^{11}$ The consent of military authorities to such exchange was initiated by, above all, lack of proper space for shooting, since the former military shooting field, near the village of Gabrovac, did not meet the standards. By order of the commanding officer of Niš garrison from 1938, caution during the shooting practice was advised, as bullets often went over badly constructed ramparts, which could endanger neighbouring farmers, particularly the ones handling the water work pump in Gabrovac. ${ }^{12}$ In any case, even with such disputes of municipal and military authorities, the tendency was to establish close cooperation of the army with the shooting societies, which was obligatory, considering the stressed role of the army in improving quality of this sport.

The shooting societies were funded, above all, by means of annual membership fee. According to data from 1933, for instance, the city members paid annual membership fees of 4 dinars, whereas members from villages paid 2 dinars. ${ }^{13}$ Besides, part time members paid half of their annual membership fee, while income was collected from charity club members (500 dinars single payment) and the founder members (1,000 dinars single payment). The shooting society from Niš had to pay $20 \%$ of their annual income into the account of the federation as fixed capital. ${ }^{14}$ However, the membership money was not sufficient

10 VA, P 17, k.255, f.3, d.18, p.1, reportof the head of engineer-technical department to the Ministry of the Army and the Navy no.14390 from 25.08.1933.

11 VA, P 17, k.256, f.1, d30, p.1, Decision of the Ministry of Finances no. 44040 from 15.11. 1933.

12 VA, P 17, k.912, f.9, d.5, p.2, Order of The commanding officer of Niš garrison from 12.09.1938. Construction works to solve this problem were not carried out. That same year, the army built the bridge over The Gabrovac river, for the needs of the shooting range 16-17 meters long and 5,5 meters wide, which was later also used by the residents. VA, P 17, к. 622, f. 2, d. 39, Decision of the command of the Morava division area from 08 June1938.

13 Three years later, membership was 20 dinars. (Revija 9. april 1936: 2).

14 AJ, 71, f 38, 123: 8. 
for maintenance of the shooting society, since the expenses included supply of ammunition, design of the shooting range, organizing competitions as well as prizes for the winners. In accordance, the Ministry of Finance prescribed the obligation to plan the needed sum in the budget so as to give financial assistance to shooting societies and provide competition prizes. In addition, the Ministry of the Army and the Navy stipulated relief for purchase of weapons and ammunition, whereas the Ministry of Agriculture joined the activity by providing 100,000 dinars annually out of statelotteryf or the shooting sport, and more precisely for design of the shooting range. ${ }^{15}$

The financial means at disposal of the shooting society in Nišs, according to available data, catered for elementary needs, such as designing of the shooting range, supply of ammunition and training. Greater and greater interest in this sport led to organization of bigger competitions such as knightly national games. The competition in Niš in 1938 raised the question of financing the making of plaquette sand cups for the winners. The Minister of social policy Dragiša Cvetković consented to this, while the Ministry of Sport later approved 3,000 dinars of onetime assistance from the budget. ${ }^{16}$ Minister Cvetković gave his approval one more time during the same year, concerning the supply of training equipment. For this purpose 5,000 dinars of the budget money was approved for the loan with financial agency from Niš. ${ }^{17}$ Ammunition was mostly supplied by military authorities, but it was also possible to buy it on the shooting range as well. At the beginning of the season of 1936, competitor shooters paid 2 dinars for the set of 5 bullets (if they were not members, the price was 5 dinars) (Revija 9. April 1936:2)

The shooting itself was organized seasonally. The beginning of the season was in April and the end in September, when a big competition at national level was held in Belgrade. Shooting was practised on Sundays, bank and clerical holidays, usually in the afternoon (Revija 9 April 1936: 2). A great number of commanding officer of the Niš garrison took part in ordinary shootings, and especially in competitions. Considering the nature of military profession, the success of officers and sub officers was to be expected. To illustrate this, we will look at the data from the competition in 1934, with the prize of 2.500 dinars. In the qualifying round, military officers and sub officers were among the best ten shooters, one of whom was general Sreten Todorović, assistant to commanding officer of the Morava division area, whereas the prize in the final round was taken by sergeant Radule Pavlović ( Niške novine 8.July 1934: 4).

The Army had a significant role in development of shooting sport in Niš. Due to its purely military competitive character, shooting was under strict

15 AJ, 71, f 1,1 .

16 AJ, 71, f.65, 198, decision of the Ministry of Sport no. 10452 from 4.11.1938.

17 AJ, 71, f 65, 198, Administration of shooting district Niš to minister of social policy and national health no.48 from 5 August, 1938. 
supervision of military authorities in the Niš garrison. Participation of the garrison and military individuals in development of this sport was important since it helped to raise consciousness of the local population through sport and military duty. The army influenced modernization of the society in terms of sport, where it was necessary to mobilise the potential of young people in Niš and direct them towards the idea of integrative Yugoslav citizenship dictated by the state.

Through shooting and other sports, young people were taught the basics of healthy living, which, in conditions of low health culture of that time in $\mathrm{Yu}$ goslavia, acted as an incentive. If we take into account the worrying rate of disabled young men, old enough to join the army (30\%), any sport activity meant a step forward in improving the conditions of healthy lifestyle. Besides, in the midst of cultural backwardness, in many cases even functional illiteracy, the promotion of sport among the population presented one of the feasible areas of modernisation.

With regard to the above mentioned facts, the role of the army in spreading literacy among the population through cultural and sports activities was significant, particularly since the male population had to pass through this institution after coming of age. During military service, they acquired knowledge and habits, while the cooperation of military and civilian authorities in the garrison meant active participation of the officers.

As far as shooting was concerned, the role of officers included both training and active participation in competitions. As founders and regular members, but also presidents of shooting societies in garrisons, there always appeared officers, often of the highest military rank. Excellent results and prizes won by officers in shooting competitions confirm the interest military authorities took in this sport.

Up to now, shooting has kept the features of a military competition with certain disciplines present also in military and police units. Above all, this stands for biathlon and practice shooting, of particular importance for training special units. Besides, shooting disciplines have kept the weapons such as army pistols, army rifles and semi automatic rifles.

All this, considering the nature of this sport, shows the key role of the army in development of shooting, far greater than in other sports. In this particular study, Niš was taken as a good example of a numerous garrison, and bearing in mind the vicinity of the border and its important strategic position in the Kingdom of Yugoslavia. The role of the army as an institution in developing shooting reflected on takeover of authority, material assistance and supervision of regular practice and competitions. Delimitation of influence with the Ministry of Sport was regulated by legal documents, which clearly defined the area of activity of the army in this sport. In the Niš garrison, considering its size and various units, the conditions for development of shooting were really favourable. 
In addition, training in handling weapons and creating of shooting clubs was also organized within the falcon society, so the sport had great success in this city. The officers themselves contributed to quality of this sport, by taking part in training and competitions, which,consequently, brought aboutgood results.

\section{UNPUBLESHED SOURCES}

Arhiv Jugoslavije (AJ), Fond 71 Ministarstvo fizičkog vaspitanja Kraljevine Jugoslavije Vojni arhiv (VA), Fond vojske Kraljevine Jugoslavije (P 17)

Istorijski arhiv Niš (IAN), zbirka Varia

\section{NEWPAPERS}

Niške novine, Niš 1934.

Revija, Niš 1936-1937.

\section{PUBLISHED SOURCES}

Službeni vojni list (SVL) 1930, 1933, Beograd, Ministarstvo vojske i mornarice.

\section{REFERENCES}

Bjelajac 1994, Mile Bjelajac, Vojska Kraljevine SHS/Jugoslavije 1922-1935, Beograd, Institut za noviju istoriju Srbije, 1994.

Brozović 1930, Ante Brozović, Soko Kraljevine Jugoslavije, Beograd, biblioteka Venac, 1930.

Velojić 2014, Dalibor Velojić, Vojska u Nišu 1918-1941, Leposavić, Institut za srpsku kulturu Priština, 2014.

Dimić 1996, Ljubodrag Dimić, Kulturna politika u Kraljevini Jugoslaviji 1918-1941, I, Beograd, Stubovi kulture, 1996.

Enciklopedija Niša, 2015, Niš, Fakultet sporta i fizičkog vaspitanja.

Žutić 1991, Nikola Žutić, Sokoli. Ideologija u fizičkoj kulturi Kraljevine Jugoslavije 1929-1941, Beograd, Angrotrejd, 1991.

Istorija Niša, 1984, Niš, Gradina.

Knežević 1931, Stevan Knežević, Vojska i sokolstvo, Ratnik, XI, Beograd, 1931, 104-113.

Panić 1927, Ilija Panić, Vojska i opšte obrazovanje naše školske omladine, Ratnik, XI-XII, Beograd, 1927, 87-95. 
Аалибор 3. ВЕАОЈИТ

УТИЦАЈ ВОЈСКЕ НА РАЗВОЈ СТРЕЉАЧКОГ СПОРТА У НИШУ 1918-1941

\section{Резиме}

Након завршетка Првог светског рата, унапређивању стрељаштва поклањала се нарочита пажња. Ово се оглеАало у доношењу законских регулатива и двојној контроли подењеној између Министарства војске и морнарице и Министарства физичког васпитања. Сврха свега овога била је милитаризација физичке културе, која се наметнула многим европским Аржавама. У самом Нишу, с обзиром на његов стратегијски положај и бројност гарнизона, сарадња војске и стрељачког друштва била је врло значајна и на обострану корист. Стрељачки спорт је увек имао материјалну потпору коА војних власти, а сами официри су своје умеће могли Аа искажу кроз такмичења. ПореА тога, стрељачке секције уведене су у соколску организацију, што је погодовало омасовњењу овог спорта и привлачењу омладине. Сходно томе, развој стрељаштва је у Нишу, као и на територији читаве земье, у међуратном периоду имао видног успеха, у чему је заскуга војске незаобилазна.

Кьучне речи: Стрељаштво, војска, Ниш, спорт, гарнизон, Соко Крањевине Југоскавије

РаА је преАат 5. априла 2021. године, а након мишьења рецензената, оАлуком одговорног уреАника Башииине, одобрен за штампу. 